\title{
Liposome encapsulated Disulfiram inhibits NFKB pathway and targets breast cancer stem cells in vitro and in vivo
}

\author{
Peng Liu ${ }^{1}$, Zhipeng Wang ${ }^{1}$, Sarah Brown ${ }^{1}$, Vinodh Kannappan', Patricia Erebi \\ Tawari $^{1}$, Wenguo Jiang ${ }^{2}$, Juan M. Irache ${ }^{3}$, James Z. Tang ${ }^{1}$, Stephen Britland ${ }^{1}$, \\ Angel L. Armesilla ${ }^{1}$, John L. Darling ${ }^{1}$, Xing Tang ${ }^{4}$ and Weiguang Wang ${ }^{1}$ \\ ${ }^{1}$ Research Institute in Healthcare Science, Faculty of Science \& Engineering, University of Wolverhampton, Wolverhampton, \\ UK \\ ${ }^{2}$ Cardiff University-Peking University Cancer Institute, Cardiff University School of Medicine, Henry Wellcome Building, Heath \\ Park, Cardiff, UK \\ ${ }^{3}$ School of Pharmacy, University of Navarra, Pamplona, Spain \\ ${ }^{4}$ School of Pharmacy, Shenyang Pharmaceutical University, Shenyang, China \\ Correspondence to: Weiguang Wang, email: w.wang2@wlv.ac.uk \\ Keywords: Breast cancer, cancer stem cells, Disulfiram, NFkappaB, chemoresistance \\ Received: May 11,2014 Accepted: July 3, $2014 \quad$ Published: July 4, 2014
}

This is an open-access article distributed under the terms of the Creative Commons Attribution License, which permits unrestricted use, distribution, and reproduction in any medium, provided the original author and source are credited.

\section{ABSTRACT}

Breast cancer stem cells (BCSCs) are pan-resistant to different anticancer agents and responsible for cancer relapse. Disulfiram (DS), an antialcoholism drug, targets CSCs and reverses pan-chemoresistance. The anticancer application of DS is limited by its very short half-life in the bloodstream. This prompted us to develop a liposomeencapsulated DS (Lipo-DS) and examine its anticancer effect and mechanisms in vitro and in vivo.

The relationship between hypoxia and CSCs was examined by in vitro comparison of $B C$ cells cultured in spheroid and hypoxic conditions. To determine the importance of NFKB activation in bridging hypoxia and CSC-related pan-resistance, the CSC characters and drug sensitivity in BC cell lines were observed in NFKB p65 transfected cell lines. The effect of Lipo-DS on the NFKB pathway, CSCs and chemosensitivity was investigated in vitro and in vivo.

The spheroid cultured BC cells manifested CSC characteristics and pan-resistance to anticancer drugs. This was related to the hypoxic condition in the spheres. Hypoxia induced activation of NFKB and chemoresistance. Transfection of BC cells with NFKB p65 also induced CSC characters and pan-resistance. Lipo-DS blocked NFKB activation and specifically targeted CSCs in vitro. Lipo-DS also targeted the CSC population in vivo and showed very strong anticancer efficacy. Mice tolerated the treatment very well and no significant in vivo nonspecific toxicity was observed.

Hypoxia induced NFKB activation is responsible for stemness and chemoresistance in BCSCs. Lipo-DS targets NFKB pathway and CSCs. Further study may translate DS into cancer therapeutics.

\section{INTRODUCTION}

Chemoresistance is the major hindrance for the success of advanced/metastatic BC (A/MBC) treatment. The relapsed $\mathrm{A} / \mathrm{MBC}$ is commonly pan-resistant to a wide range of anticancer drugs, which cannot be explained by individual genetic and biochemical resistant pathway. BC is a highly heterogeneous disease containing a very small fraction (1\%) of cancer stem cell (CSC) [1] population with stem cell characters e.g. self-renewal, development into the original tumors in immune deficient mice, differentiation into several linages of progenies. BCSCs can be detected by stem cell markers (ALDH ${ }^{+}, \mathrm{CD} 24^{\text {Low/ }}$ CD44 $\left.{ }^{\text {High }}\right)$ and activation of embryonic related pathways (Sox2, Oct4, Nanog) [2]. BCSCs are relatively quiescent 
and pan-chemoresistant [3, 4]. Conventional anticancer drugs fail to eradicate the BCSCs, which become the source of tumor recurrence.

Emerging evidence suggests that CSCs reside in a hypoxic/necrotic tumorous area named the CSC niche [5]. A wide range of studies has demonstrated that hypoxia plays pivotal roles in maintenance of the stemness of CSCs. The hypoxia-induced CSC characteristics can be reversed into a differentiated phenotype in normoxic condition and vice versa. In vitro, the CSC and nonCSC phenotypes are interconversible in spheroid and monolayer culture respectively $[6,7]$. Therefore the environmental oxygen concentration plays determinant roles in maintaining stemness in CSCs [8]. Although most of the publications emphasize the importance of the hypoxia inducible factors (HIFs) in induction and maintenance of CSC phenotypes, the molecular links between hypoxia and CSCs are still not fully elucidated. More than 20 transcription factors including $\mathrm{NF \kappa B}$ are induced by hypoxia [9]. Hypoxia induces $N F \kappa B$ activation in a wide range of cells [6]. NFKB plays important role in cell survival, proliferation, invasion, migration and chemoresistance $[10,11]$. Human NFkB is composed of 5 subunits [p50/p105, p52/p100, p65 (RelA), RelB and c-Rel], which form homo- or heterodimer binding to DNA target sites ( $\kappa \mathrm{B}$ sites) to influence downstream gene expression. The most common dimer is a p50-RelA heterodimer. In most normal cells, NFkB is sequestered in the cytoplasm as an inactive complex through the direct binding to its natural inhibitor, the inhibitor of NFKB

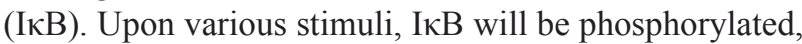
ubiquitinated and promptly degraded which releases NFkB

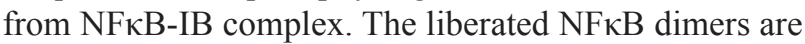
then translocated into the nucleus and trigger a series of molecular reactions. Hypoxic activation of NFkB pathway may be HIF $1 \alpha$-dependent. HIF $1 \alpha$ may directly interact with $\mathrm{NF} \kappa \mathrm{B}$ proteins to promote its DNA binding activity [12-14]. In addition to HIF-mediated activation of NFKB, it is recently demonstrated that hypoxia can directly induce NFKB which in turn regulates HIF pathway. The promoter region of HIF $1 \alpha$ contains $\kappa \mathrm{B}$ site. The activation of NFkB induced by $\mathrm{TNF} \alpha$ and $\mathrm{p} 50 / \mathrm{p} 65$ transfection lead to increased levels of HIF $1 \alpha$ mRNA and protein. Therefore NF- $\kappa B$ can regulate HIF $1 \alpha$ signaling pathway to maintain the basal levels of HIF $1 \alpha$ under normoxic condition and further induces it under hypoxia $[15,16]$. $\mathrm{NF} \kappa \mathrm{B}$ also induces HIF2 $\alpha$ activation via influence of the interaction between IKK $\gamma$ and CBP/p300 [17, 18]. Recent studies indicate that $\mathrm{NF \kappa B}$ plays a pivotal role in hypoxia-induced CSC phenotypes and is responsible for the chemoresistance in CSCs [19].

It is widely accepted that development of antiCSC drugs to target CSC determinant pathways will improve chemotherapeutic outcomes. Disulfiram (DS), a commercially available anti-alcoholism drug [20], shows anticancer activity in vitro and in vivo [21-24].
Our previous studies demonstrate that DS enhances 5-fluorouracil, paclitaxel (PTX) and gemcitabine (dFdC) induced apoptosis in colon, breast and brain cancer cell lines [21, 25-27]. The randomized clinical trial indicates that in combination with chemotherapy, ditiocarb, the derivative of DS, significantly improves the 5 -year overall survival of high risk BC patients [28]. The anticancer activity of DS is copper $(\mathrm{Cu})$ dependent $[22,29]$. Cu plays a crucial role in redox reactions and triggers the generation of reactive oxygen species (ROS) in human cells. DS/ $\mathrm{Cu}$ is a strong ROS inducer [30] and proteasome-NFKB pathway inhibitor $[21,22,25]$. DS specifically inhibits the activity of aldehyde dehydrogenase (ALDH), a functional marker of CSCs and ROS scavenger [31,32]. Combination of DS with $\mathrm{Cu}$ may target cancer cells by simultaneous modulation of both ROS and NFKB. DS and its metabolites can also permanently inhibit Pgp activity [33].

Although the anticancer activity of DS has been reported for a long time, only very few successful cases have been reported in clinic [28, 34]. This discrepancy may be mainly introduced by the very short half-life of DS in the bloodstream. Nano-technology may be able to extend the half-life of DS and translate it into cancer indication. In this study, we investigated the effect of hypoxia on CSCs and elucidated the bridging role of $\mathrm{NF \kappa B}$ in linking hypoxia and CSCs. We also examined the in vitro and in vivo anticancer efficacy of a newly developed liposome-encapsulated DS (Lipo-DS). Our data indicate that $\mathrm{NF \kappa B}$ plays a key role in pan-resistance of hypoxia-induced CSCs. Lipo-DS can efficiently abolish CSCs and reverse chemoresistance.

\section{RESULTS}

\section{Hypoxia is responsible for maintaining stemness and drug resistance in mammosphere (MSC) and suspension cells (SUS)}

In this study, we examined if the traditional stem cell culture system is essential for maintaining the stemness in vitro. Two breast cancer cell lines were cultured in both classical serum-free spheroid stem cell culture system and serum-rich (10\%) medium in parallel. After 7 days culture, $\mathrm{BC}$ cells formed typical mammospheres in both conditions. The serum-free medium cultured cells formed numerous relatively smaller spheres which loosely aggregated together. In contrast, the cells cultured in the serum-rich medium formed markedly larger and tighter spheres (Fig. 1A). Furthermore, we compared the expression of stem cell markers and CSC-related embryonic proteins in these cells. Both MSCs and SUS cells have significantly higher proportion of cells expressing stem cell markers $\left(\mathrm{ALDH}^{+}\right.$and $\left.\mathrm{CD} 24^{\text {low }} / \mathrm{CD} 44^{\text {high }}\right)$ and $\mathrm{CSC}$ - 
Table 1: Cytotoxicity of conventional anticancer drugs in $\mathrm{BC}$ cell lines

\begin{tabular}{|c|c|c|c|c|c|c|}
\hline & \multicolumn{3}{|l|}{ MCF7 } & \multicolumn{3}{|l|}{ T47D } \\
\hline & $\mathrm{dFdC}$ & Dox & PTX & $\mathrm{dFdC}$ & Dox & PTX \\
\hline ATT & $28.7(7.6)$ & $17.1(1.1)$ & $6.3(1.6)$ & $76.3(5.7)$ & $64.2(2.4)$ & $7.7(2.4)$ \\
\hline $\mathrm{MSC}$ & $>1000$ & $>2000$ & $>1000$ & $>1000$ & $>2000$ & $>1000$ \\
\hline SUS & $>1000$ & $>2000$ & $>1000$ & $>1000$ & $>2000$ & $>1000$ \\
\hline Нуро & $>1000$ & $>2000$ & $>1000$ & $>1000$ & $>2000$ & $>1000$ \\
\hline Mock & $14.8(5.2)$ & $63.2(12.9)$ & $2.8(0.4)$ & $2.5(2.0)$ & $169.8(42.5)$ & $6.2(1.8)$ \\
\hline $\mathrm{C} 2$ & $>1000$ & $424.3 * *(65.5)$ & $>1000$ & N/A & $\mathrm{N} / \mathrm{A}$ & $\mathrm{N} / \mathrm{A}$ \\
\hline $\mathrm{P} 1$ & $>1000$ & $159.8 * *(36.8)$ & $>1000$ & $\mathrm{~N} / \mathrm{A}$ & $\mathrm{N} / \mathrm{A}$ & $\mathrm{N} / \mathrm{A}$ \\
\hline $\mathrm{C} 1$ & $\mathrm{~N} / \mathrm{A}$ & N/A & N/A & $>1000$ & $498 * *(130)$ & $>1000$ \\
\hline C3 & N/A & N/A & N/A & $>1000$ & $>1000$ & $>1000$ \\
\hline
\end{tabular}

The figure represents $\mathrm{IC}_{50}$ value from three MTT experiments [mean (SD)]. The cells were exposed to drugs for 72 hours. ATT: attached cells; MSC: mammosphere cells; SUS: suspension culture in normal medium; Hypo: hypoxic culture $\left(\mathrm{O}_{2}<1 \%\right)$. Mock: Empty vector transfected cells; C2, P1, C1, C3: NFкB p65 transfected clones. $* *$ p $<0.01$

$(n=3)$ compared with Mock cells.

related embryonic proteins (Sox2, Nanog and Oct4). In comparison with the MSCs, most of these proteins are expressed at higher levels in the SUS cells (Fig. 1B). CSCs commonly possess de novo resistance to a wide range of anticancer drugs [1]. Furthermore we examined the chemosensitivity in these cells. Table 1 shows that resistance of $\mathrm{BC}$ cells to three first line anti-BC drugs was induced in both culture systems. These results suggest that the stemness and chemosensitivity in BC cells were not governed by the components in the culture medium. It has been reported that the hypoxic condition in the stem cell niche is essential for maintaining the stemness and chemoresistance [6]. We hypothesized that the hypoxic condition in the mammospheres may play the role in maintenance of stemness and chemoresistance. Fig. 1D and $1 \mathrm{E}$ demonstrate that in comparison with the adherent cells, high population of hypoxic cells were detected in both MSC and SUS cells by HypoxyProbe. Furthermore we cultured both cell lines in hypoxic condition $(1 \%$ $\mathrm{O}_{2}$ ) for 5 days to determine the relationship between hypoxia and MSC characteristics. Fig. $1 \mathrm{~F}$ to $1 \mathrm{H}$ show that the hypoxia-cultured monolayer cells express MSC markers and embryonic proteins. Similar to the MSC and SUS cells, the cells cultured in hypoxic condition are significantly resistant to chemotherapeutic agents (Table 1). All of these data indicate that hypoxia may play a key role in determination of stemness and chemosentivity in $\mathrm{BC}$ cells.

\section{NFкB activation plays a pivotal role in maintaining CSC stemness and chemoresistance}

High HIF2 $\alpha$ nuclear protein was detected in the cells cultured in hypoxia, MSC and SUS conditions. $\mathrm{I} \kappa \mathrm{B} \alpha$ degradation and $\mathrm{NF} \kappa \mathrm{B}$ p65 nuclear translocation were detected (Fig. 2A and 2B). NFאB p65 and AKT Phosphorylation and increased NFאB DNA binding activity were also detected in these cells (Fig. 2B and 2C). These results indicate that $\mathrm{NF} \kappa \mathrm{B}$ may be the pivotal factor in hypoxia-induced CSC characteristics. To examine the importance of $\mathrm{NF} \kappa \mathrm{B}$ in maintenance of stemness and chemosensitivity, both MCF7 and T47D cell lines were transfected with NFאB p65 subunit. High p65 protein levels and transcriptional activity of NFkB were detected in the transformed clones (Fig. 2D and 2E). Fig. 2F shows that the transformed clones possess significantly higher $(\mathrm{p}<0.01)$ population of CSCs $\left(\mathrm{ALDH}^{+}, \mathrm{CD} 24^{\text {low }} / \mathrm{CD} 44^{\text {high }}\right)$. In comparison with the mock-transfected cells, the p65 transfected cell lines are highly resistant to three first line anti-BC drugs [doxorubicin (Dox), PTX and $\mathrm{dFdC}$ ] (Table 1). These data suggest that NFאB plays a key role in hypoxia-induced CSCs and chemoresistance.

\section{Lipo-DS targets CSCs in vitro}

$\mathrm{CuCl}_{2}(10 \mu \mathrm{M})$ was used in all the experiments because $\mathrm{Cu}$ is essential for DS induced cytotoxicity [21, $27,35]$. Lipo-DS/Cu was highly cytotoxic to MSCs (Fig. $3 \mathrm{~A})$ although these cells are resistant to conventional antiBC drugs (Table 1). Lipo-DS/Cu induced and inhibited expression of $\mathrm{Bax}$ and $\mathrm{Bcl} 2$ proteins respectively (Fig. 3B). The sphere-forming ability was also completely abolished after 4 hours exposure to Lipo-DS/Cu but not Lipo-DS and $\mathrm{Cu}$ alone (Fig. 3C). The $\mathrm{ALDH}^{+}$and $\mathrm{CD} 24^{\text {low }} / \mathrm{CD} 44^{\text {high }} \mathrm{CSC}$ population in the mammospheres was eliminated by Lipo-DS/Cu but not Lipo-DS, $\mathrm{Cu}$ and anti-BC drugs (Fig. 3D and 3E). Four ALDH isoenzymes (1A1, 1A3, 2 and 3A1) are most possible to be involved in the ALDH activity in CSCs [32, 36-38]. The mRNA and protein of these isoenzymes were examined to determine if Lipo-DS also inhibits ALDH at transcriptional and translational levels. Although most of the previous publications mentioned that ALDH1A1 is responsible for ALDH activity in CSCs, we could not detect its expression in both attached and sphere-cultured MCF7 and T47D 

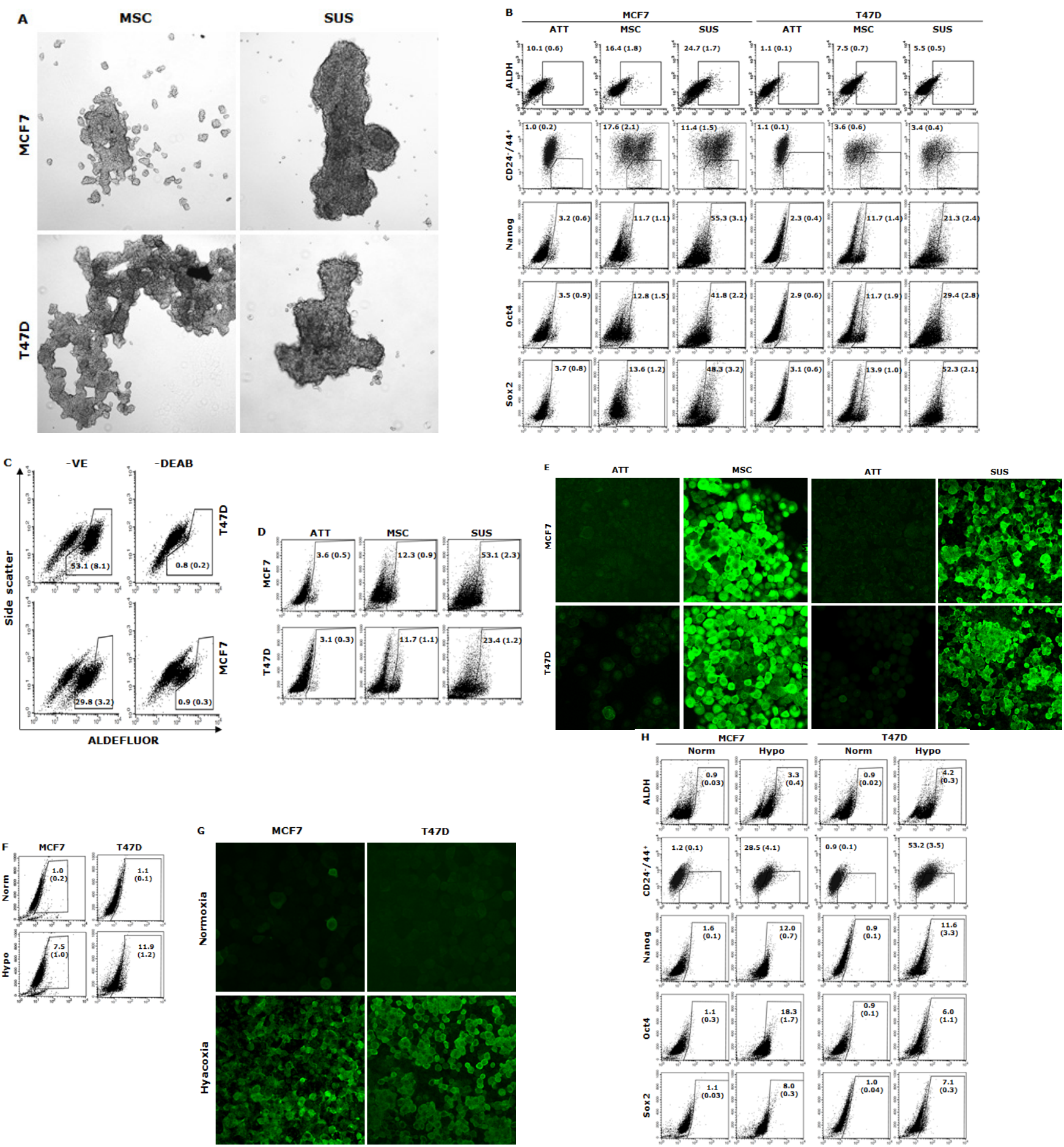

Figure 1: Hypoxia induces expression of stem cell markers in BC cell lines. A. The morphology of spheres cultured in serumfree (MSC) and serum-containing (SUS) medium (40× magnification). B. Flow cytometric analysis of ALDH activity and expression of CD24, CD44, Oct4, Sox2 and Nanog proteins in monolayer- and suspension-cultured cells. In comparison with the attached cells, all of these markers are expressed significantly higher in MSC and SUS ( $<<0.01)$. C. Specificity of ALDEFUOR in detection of ALDH activity in BC cell lines. DEAB: specific inhibitor of ALDH. D. Flow cytometric detection of hypoxic cells stained with Hypoxyprobe. Significantly higher population of hypoxic cells was detected in MSC and SUS cells $(\mathrm{p}<0.01)$. E. Confocal microscopy images of the hypoxic cells detected by Hypoxyprobe in serum-free (MSC) and serum-containing (SUS) medium cultured BC cells ( $\times 400$ magnification). $F$ and G. Hypoxyprobe stained hypoxic population in hypoxia-cultured BC cells was detected by flow cytometry (F) and immunocytochemistry (G) respectively. H. Flow cytometric comparison of ALDH activity and expression levels of CD24, CD44, Oct4, Sox2 and Nanog proteins in normoxia- and hypoxia-cultured cells. In comparison with the normoxic cells, stem cell markers were detected in significantly higher population of the hypoxic cells $(\mathrm{p}<0.01)$. ATT: monolayer culture; MSC: serum-free stem cell culture; SUS: serum-containing medium culture; Norm: normoxia; Hypo: hypoxia. The numbers in the frame represent Mean (SD) from three experiments. 

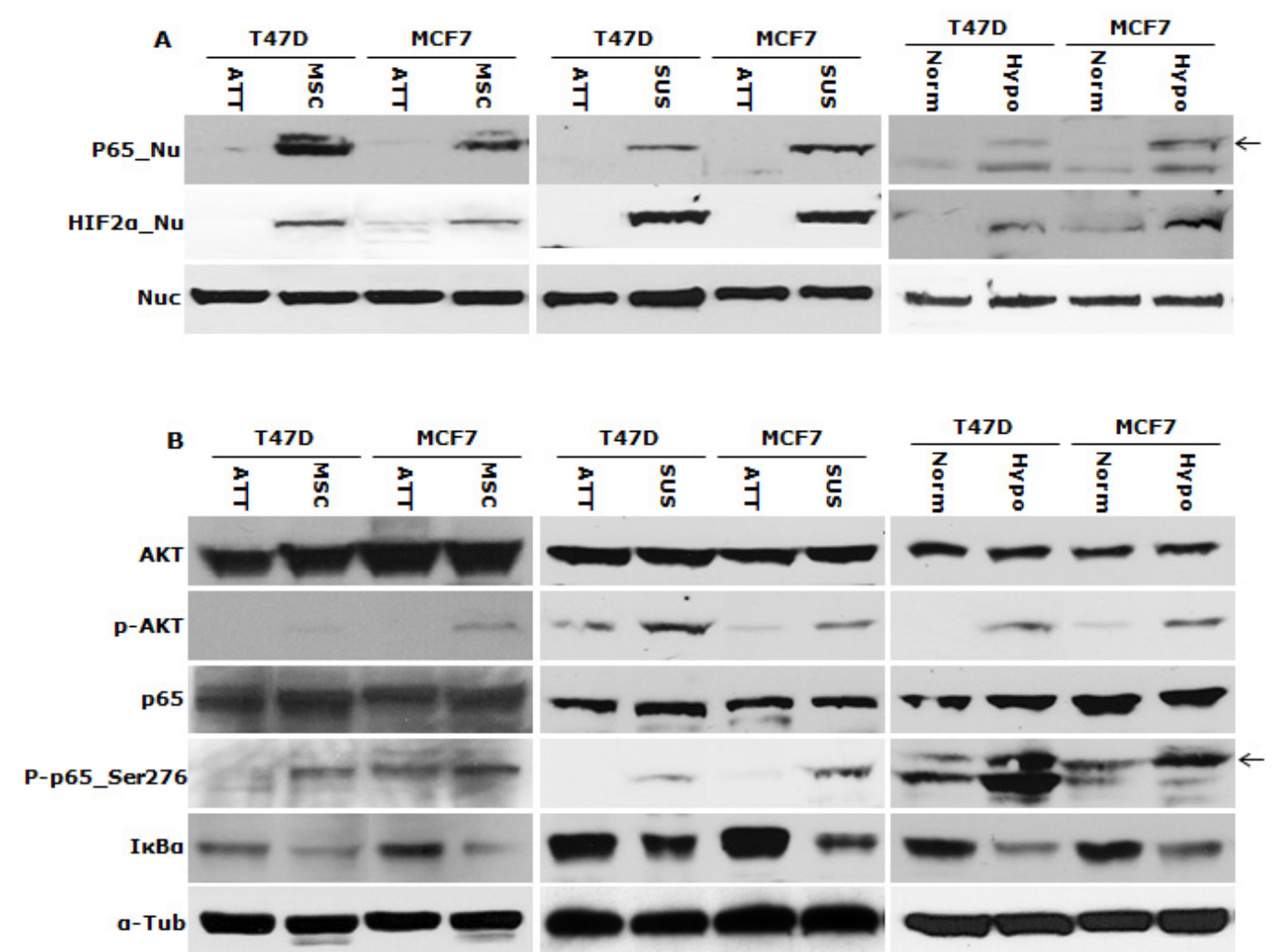

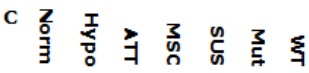
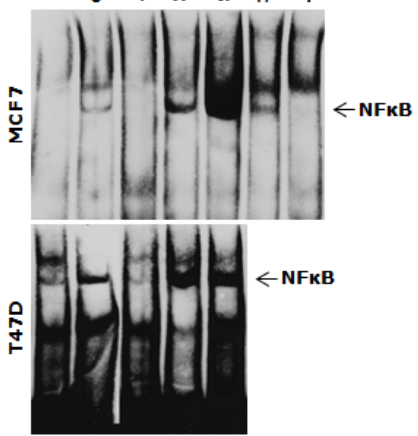

$\mathbf{F}$
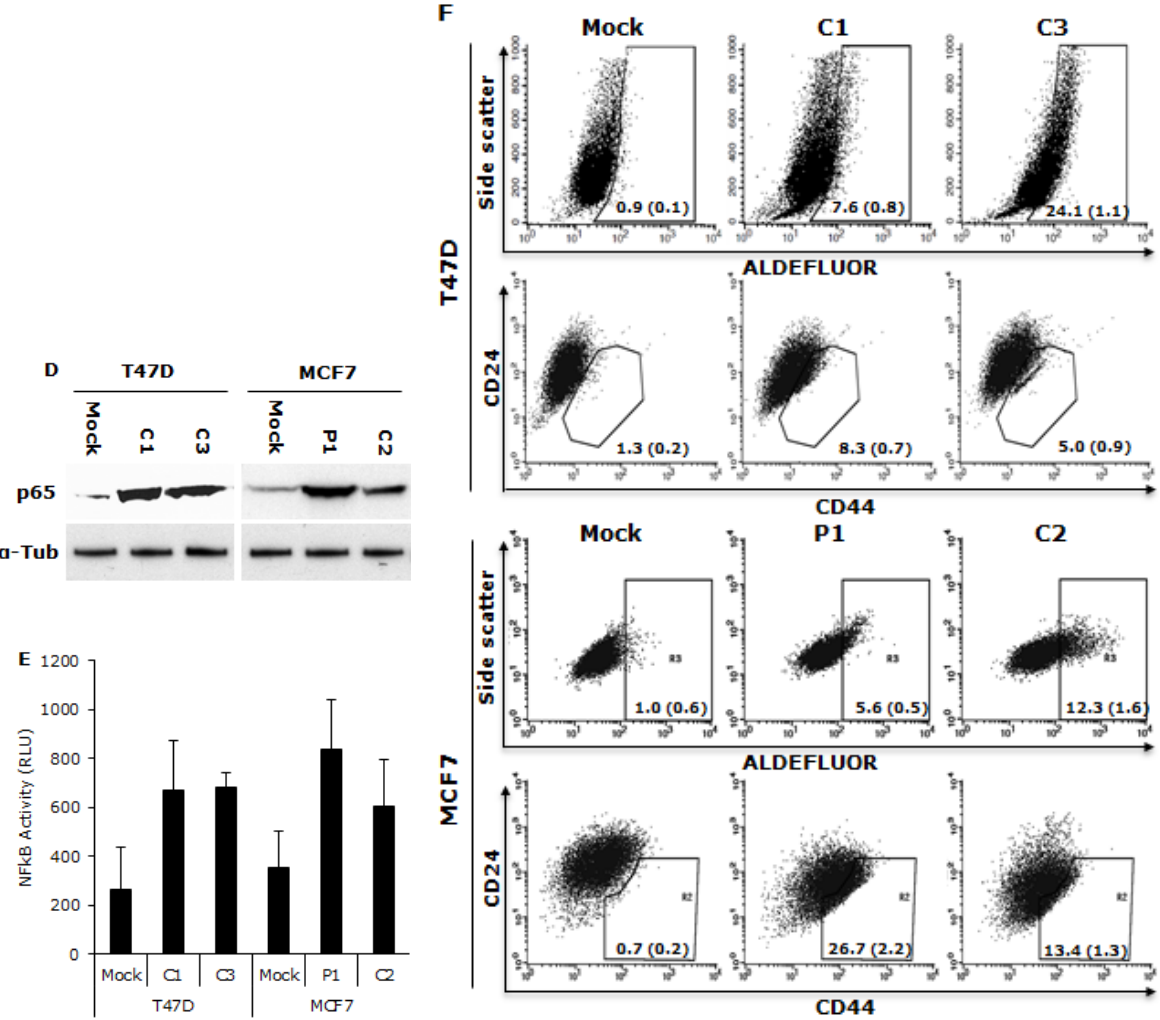

Figure 2: $\mathrm{NF \kappa B}$ is responsible for maintaining CSC characters in suspension- and hypoxia-cultured cells. A. High levels of NFKB p65 and HIF2 $\alpha$ protein were detected in the nuclear protein extracted from suspension- and hypoxia-cultured cells. Nuc: nucleolin

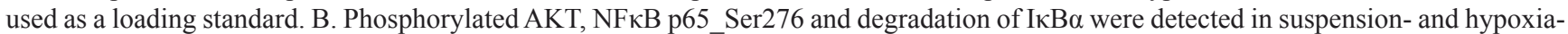
cultured cells by western blot. $\alpha$-Tub: $\alpha$-tubulin used as a loading control. C. High NFאB DNA binding activity was detected by EMSA. Mut and WT: mutant and wild type probe competition. D and E. High NFאB p65 protein (D) and transcriptional activity (E) were detected in p65 transfected clones $(\mathrm{C} 1, \mathrm{C} 3, \mathrm{P} 1$ and $\mathrm{C} 2)$ by western blot and luciferase reporter gene assay respectively. Mock: empty vector transfected cells. F. High $\mathrm{ALDH}^{+}$and $\mathrm{CD} 24^{\text {low }} / \mathrm{CD} 44^{\text {high }}$ population was detected in NFKB p65 transfected clones. 

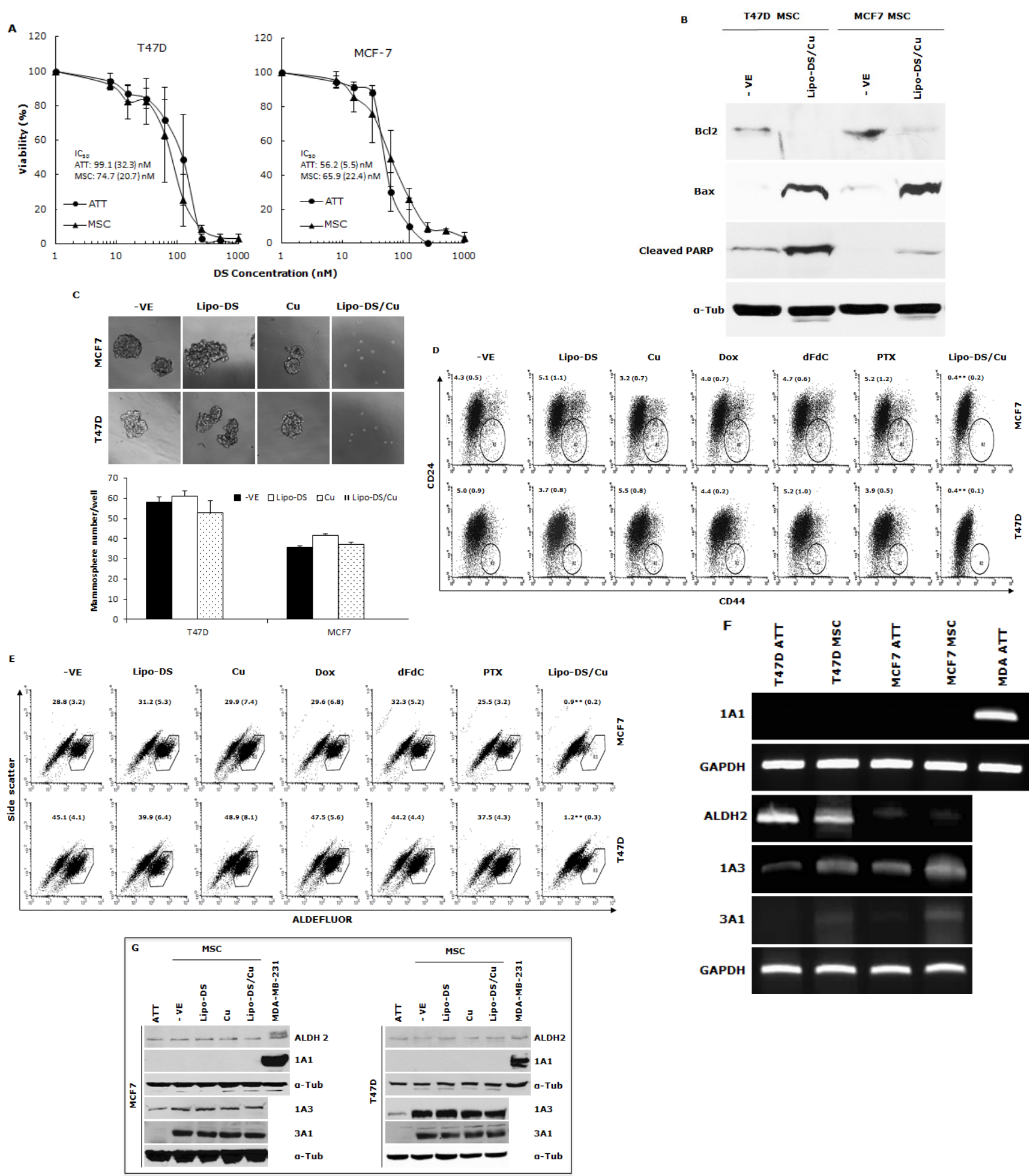

Figure 3: Cytotoxic effect of Lipo-DS/Cu on BCSCs. A. Comparable cytotoxicity of Lipo-DS/Cu in monolayer-cultured cells and BCSCs was detected by MTT assay. The cells were exposed to Lipo-DS/Cu for 72 hours. B. Lipo-DS/Cu induced Bax and cleaved PARP and reduced Bcl2 expression were detected by western blot. The cells were treated in Lipo-DS $(1 \mu \mathrm{M}) / \mathrm{CuCl}_{2}(10 \mu \mathrm{M})$ for 4 hours and in drugfree free stem cell culture medium for 24 hours. C. Lipo-DS/Cu abolished sphere-forming ability in BC cell lines. The cells were cultured in Lipo-DS $(1 \mu \mathrm{M}), \mathrm{CuCl}_{2}(10 \mu \mathrm{M})$ or Lipo-DS/ $\mathrm{CuCl}_{2}$ for 4 hours and in drug-free free stem cell culture medium for 7 days. D. The effect of different treatments on CD24 ${ }^{\text {low }} / C D 44^{\text {high }}$ population. E. The effect of different treatments on ALDH activity in BCSCs. For experiments D and E, 7-day-cultured sphere cells were trypsinized and exposed to different agents for 4 hours, then released for 24 hours. (** in D and E: In comparison with other groups, $\mathrm{p}<0.01) \mathrm{F}$. Expression of ALDH mRNAs in attached and spheroid cells. G. Lipo-DS/Cu did not influence the expression of ALDH proteins in CSCs. The whole proteins were extracted from the BCSCs exposed to different agents for 4 hours and released in drug-free medium for 24 hours. 
cells. ALDH2, a mitochondria-located isoenzyme, was expressed at background levels and not induced in CSCs. In contrast, the mRNA and protein of ALDH1A3 and 3A1 were expressed at very low levels in the attached cells and markedly induced by MSC culture (Fig. 3F and 3G). Therefore ALDH1A3 and 3A1 may contribute to the high ALDH activity in the CSCs derived from MCF7 and T47D cell lines. Although Lipo-DS/Cu inhibited ALDH activity but it had no effect on the mRNA and protein expression of these 4 isoenzymes.

\section{Lipo-DS/Cu simultaneously triggers ROS-MAPK activation and inhibits NFKB pathway in MSCs}

We previously reported that $\mathrm{DS} / \mathrm{Cu}$ activates $\mathrm{ROS}$ MAPK and inhibits NFאB pathways in attached cells
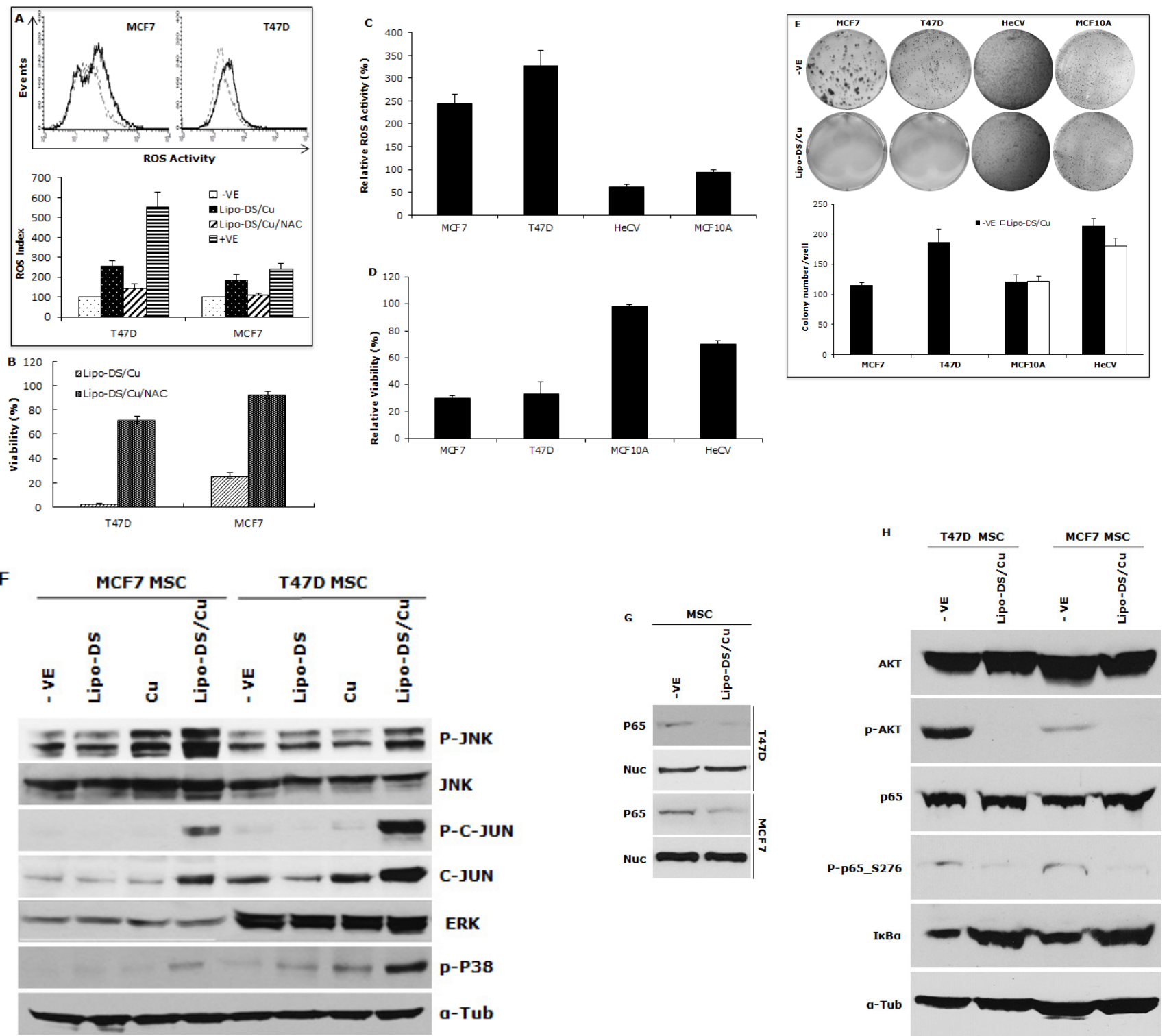

Figure 4: Lipo-DS/Cu induces ROS-MAPK and inhibits NFאB pathways and specifically targets BC cells. A. Top: Flow cytometric detection of Lipo-DS/Cu-induced ROS activity in BC cells. Dot-line: control, Solid-line: Lipo-DS/Cu. Bottom: Lipo-DS/Cuinduced ROS activity was reversed by NAC. +VE: positive control (Pyocyanin 200 $\mu$ M). B. The Lipo-DS/Cu-induced cytotoxicity was reversed by NAC. C. Lipo-DS/Cu specifically induced ROS activity in BC cell lines. Relative ROS activity $=($ Treated/untreated $) \times 100 \%$. D. Lipo-DS/Cu demonstrated specific cytotoxicity in $\mathrm{BC}$ cell lines. Relative viability $=($ Treated/untreated $) \times 100 \%$. E. Clonogenic assay shows that Lipo-DS/Cu abolished colony-forming ability in $\mathrm{BC}$ cell lines but no effect on normal cell lines. The cells were exposed to drugs for 1 hour and released in drug free medium for 72 hours (MTT) and 10 days (clonogenic assay). F. The effect of different treatments

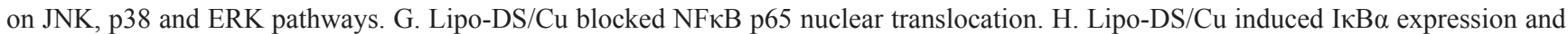
inhibited phosphorylation of AKT and NFkB p65. For F - H, 6-day-cultured spheres were trypsinized and exposed to different treatments (Lipo-DS $1 \mu \mathrm{M}, \mathrm{Cu} 10 \mu \mathrm{M}$, Lipo-DS/Cu) for 4 hours and release in drug-free medium for 24 hours. 

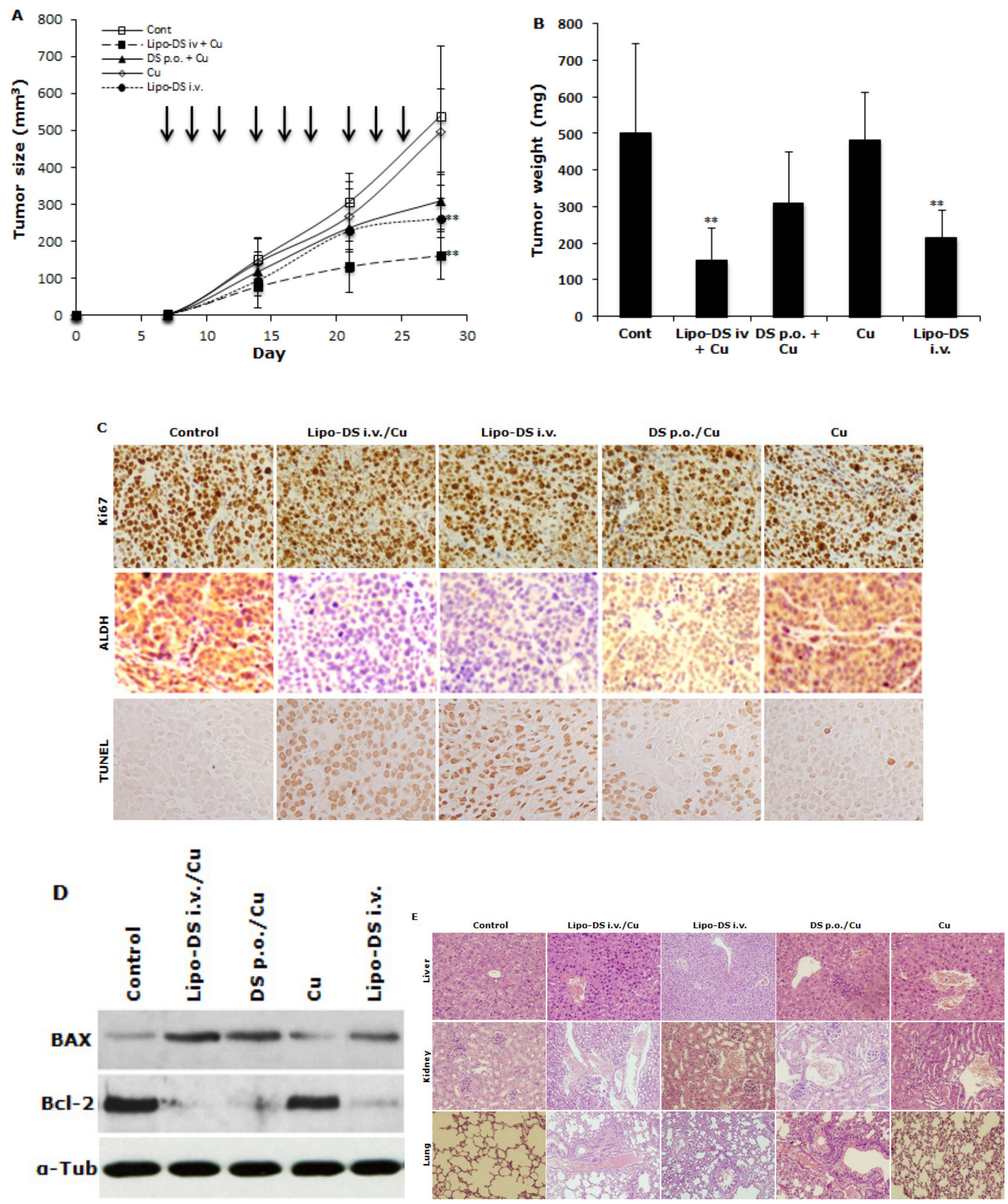

Figure 5: Lipo-DS inhibited growth of BC xenografts. MDA-MB-231 cells $\left(1 \times 10^{6}\right)$ were subcutaneously injected at one rear flank of the mice. When the tumor volume reached $\sim 200 \mathrm{~mm}^{3}$, the tumor bearing mice were randomly subdivided into 5 groups (8 mice/group) e.g. control; DS 75mg/kg p.o + CuGlu 8mg/kg p.o; CuGlu 8mg/kg p.o; Lipo-DS 75mg/kg i.v; Lipo-DS $75 \mathrm{mg} / \mathrm{kg}$ i.v + CuGlu $8 \mathrm{mg} / \mathrm{kg}$ p.o. The drugs were administered 3 times/week for successive 3 weeks. A. Growth curves of tumor size. Arrows represent drug administration. B. The effect of different treatments on tumor weight after 28 days observation. C. The effect of different treatment on Ki67 and TUNEL expression ( $\times 400$ magnification). D. The effect of different treatments on BAX and Bcl-2 expression. E. Histo-pathological images of vital organs (H\&E staining, 400 magnification). 
[21]. In this study, we examined the effect of Lipo-DS/ $\mathrm{Cu}$ on MSCs. Lipo-DS/Cu induced ROS activity in MSCs was reversed by NAC, a ROS inhibitor. NAC also reversed Lipo-DS/Cu induced cytotoxicity (Fig. 4A and B). In comparison with normal cell lines, Lipo-DS/Cu selectively induced higher ROS activity and cytotoxicity in cancer cells (Fig. 4C and 4D). After exposure to Lipo-DS/Cu for one hour, the clonogenicity in cancer cell lines was completely abolished but no significant effect was observed in Lipo-DS/Cu treated normal cells (MCF10A and HeCV)(Fig. 4E). After exposure to Lipo$\mathrm{DS} / \mathrm{Cu}$ for 4 hours, the major MAPK pathway elements, e.g. phosphorylated JNK, phosphorylated C-JUN and phosphorylated p38 but not ERK, were significantly induced (Fig. 4F). In contrast to the MAPK pathway, Lipo-

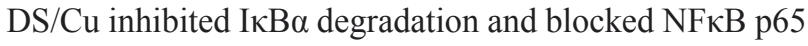
nuclear translocation in both MCF7 and T47D CSCs. The phosphorylation of NFkB p65 and AKT in the MSCs was also inhibited by Lipo-DS/Cu (Fig. 4G and 4H).

\section{Disulfiram inhibits BC xenografts in vivo}

Furthermore, the anticancer efficacy of LipoDS was examined in vivo. The drug was administered 3 times/week for successive 3 weeks. To determine the necessity of copper supplement in vivo, the Lipo-DS i.v with/without copper supplement and copper alone were compared. The oral administration of DS/copper gluconate (CuGlu) was compared with i.v administration of LipoDS plus oral administration of CuGlu. In comparison with the control group, both Lipo-DS/CuGlu and Lipo-DS significantly inhibited tumor growth but Lipo-DS/CuGlu demonstrated highest anticancer efficacy (Fig. 5A and 5B). Oral administration of DS/CuGlu also showed tumor inhibiting effect although it is not statistically significant. Copper alone had no effect on tumor growth. Lipo-DS/ CuGlu, Lipo-DS and DS/CuGlu induced BAX, inhibited Bcl-2 and induced TUNEL staining (Fig. 5C and 5D). In comparison with the control group, the ALDH expression in tumor tissues was inhibited when the animal were treated with Lipo-DS/CuGlu and Lipo-DS (Fig. 5C). It seems that Lipo-DS/CuGlu had no effect on proliferation because the expression of Ki67 was not affected by the treatments. Administration of CuGlu with or without DS or Lipo-DS induced moderate dilation of blood vessels in the examined organs. No cytotoxic effect was observed in lung and kidney but some necrotic cells were observed in the liver of Lipo-DS/CuGlu treated animals (Fig. 5E).

\section{DISCUSSION}

Since Al-Hajj identified CSCs in BC [39], the existence of CSCs has been reported in several other cancer types and in developed cancer cell lines [40]. The CSC culture system is adapted from the normal stem cell culture system. The serum-free and growth factors-supplemented spheroid culture has been widely used as a gold method in vitro to prevent differentiation, purge the differentiated progenies and enrich stem cell population [41]. In contrast to the relatively nonreversible differentiation in normal stem cells, the monolayercultured non-CSCs and sphere-cultured CSCs are completely reversible $[6,41]$. In comparison with the stem cell culture system, the serum-rich suspended culture system is less costly and has better physiological relevance. In this study, we compared the BC cells cultured in traditional serum-free stem cell medium and serum-rich ( $10 \%$ FCS) medium to determine the necessity of the stem cell medium in maintaining the CSC status. After 6 days culture, the BC cells in both systems formed spheres and clusters (Fig. 1A). It is widely accepted that if it is not a single cell inoculation, the aggregation of the suspended cells is inevitable, no matter how low the cell density ([41] and our unpublished data). Therefore, these spheres and clusters represent both cell proliferation and aggregation. The expression of stem cell and embryonic markers was significantly induced in the cells cultured in both systems. This result indicates that the stemness was not determined by the components in the culture medium. If so, there must be some common feature(s) in the culturing systems which introduce and maintain stemness. Hypoxia is a determinant of stemness in stem cell niche [6]. We hypothesized that due to the penetrating distance hypoxia may be cumulated within the spheres. The cells located in the center of the spheres will show CSCs' characteristics. Compared with the monolayer-cultured cells, a high population of hypoxic cells was detected in the spherecultured cells (Fig. 1D and E). More hypoxic cells were detected in serum-containing spheres. This may be due to that these spheres are significantly bigger and tighter than those in serum-free culture (Fig. 1A). A high population of CSCs was also detected in hypoxia-cultured $\left(<1 \% \mathrm{O}_{2}\right)$ BC cells. The $\mathrm{BC}$ cells cultured in these three conditions are highly resistant to $\mathrm{dFdC}$, Dox and PTX. Chemoresistance is another common feature of CSCs. These results indicate that the stem cell characters in the sphere-cultured cells may be introduced by hypoxia. The serum-free and growth factors-supplemented medium is not essential for the in vitro CSC culture.

Although hypoxia can induce stem cell characters, the detailed molecular mechanisms and pathways linking hypoxia and CSCs are still largely unknown. It is generally believed that hypoxia-activated HIF pathways are important for cellular response to hypoxia [6]. However, many other transcription factors, e.g. $\mathrm{NF \kappa B}$, are also crucial for hypoxia-induced phenotypes. Activation of NFKB pathway enables the survival of the inflammatory cells in inflammation-induced hypoxia [6]. Recent studies indicate that NFкB also plays a pivotal role in CSCs and chemoresistance [42-44]. In our study, nuclear translocation of HIF $2 \alpha$ and NFkB p65 protein 
was detected in sphere- and hypoxia-cultured cells. These cells also demonstrated $\mathrm{I} \kappa \mathrm{B} \alpha$ degradation and $\mathrm{p} 65$ phosphorylation. The activation of AKT, the transcription factor upstream of $\mathrm{NF} \kappa \mathrm{B}$, was also observed. High $\mathrm{NF} \kappa \mathrm{B}$ DNA binding activity was induced in all three conditions. Therefore NFkB pathway is activated in all of the three culture systems (MSC, SUS and hypoxia). In order to examine the importance of $\mathrm{NF} \kappa \mathrm{B}$ in determination of CSC traits, we transfected $\mathrm{BC}$ cells with NFkB p65. The transfected clones expressed high levels of BCSC markers (Fig. 2F) and were highly resistant to $\mathrm{dFdC}$, Dox and PTX (Table 1). Therefore NFאB definitely conferred CSC traits upon BC cells.

DS is an NFאB inhibitor which targets CSCs and reverses chemoresistance [21, 25, 27, 35, 45]. The application of DS in cancer therapeutics is limited by its very short half-life in the bloodstream [46]. To overcome this hindrance, we recently developed a Lipo-DS to extend the half-life of DS in the bloodstream [47]. In line with our previous reports [21, 27], the cytotoxicity of Lipo-DS is $\mathrm{Cu}$ dependent. After very short exposure (4 hours) to Lipo-DS/Cu, the expression of BCSC markers $\left(\mathrm{ALDH}^{+}\right.$, $\left.\mathrm{CD} 24^{\text {low }} / \mathrm{CD} 44^{\text {high }}\right)$ in the sphere cells was inhibited and the sphere-forming ability in the BC cell lines was completely abolished. The BCSC markers were not affected by conventional anticancer drug, Lipo-DS or Cu. Although it was reported that ALDEFLOUR detects enzyme activity of ALDH1A1 [32], we could not detect ALDH1A1 mRNA and protein expression in both cell lines. ALDH2, a mitochondrial isoenzyme, was detected at very low basal levels but not induced by spheroid and hypoxic culture. Marcato et al. [36] reported that ALDH1A3 is responsible for the high ALDH activity in BC. Our study indicates that both ALDH1A3 and 3A1 may be responsible for the high ALDH activity in BCSCs because high and inducible expression of ALDH1A3 and 3A1 mRNA and proteins was detected in sphere-cultured cells. Lipo-DS/Cu had no effect on ALDH isoenzymes (1A1, 1A3, 2 and 3A1) at mRNA and protein levels.

Selectivity is one of the key issues for anticancer drug development. The cytotoxicity of Lipo-DS/Cu is ROS dependent. ROS induces apoptosis by damaging DNA, RNA and protein. Cancer cells possess and also tolerate significantly higher levels of ROS due to the balance of anti-apoptotic mechanisms e.g. NFאB [48]. Lipo-DS/Cu selectively induced ROS activity and showed significantly higher cytotoxicity in BC than normal cell lines. Similar phenomenon was also obtained by clonogenic assay (Fig. 4E). ROS induced-apoptosis is highly MAPK pathwaydependent. Lipo-DS/Cu persistently activated JNK, C-Jun and p38 MAPK pathways but had no effect on ERK pathway which is responsible for cell growth, proliferation and survival [49]. ROS also trigger the expression of anti-apoptotic proteins which in turn neutralize the proapoptotic effects of ROS [48]. NFKB is one of the most important ROS-induced anti-apoptotic factors [48]. NFאB inhibits JNK and p38 activation and suppresses ROS accumulation in cancer cells $[48,50]$. Cancer cell fate is highly dependent on the crosstalk between $\mathrm{JNK} / \mathrm{p} 38$ and NF $\kappa$ B pathways. Simultaneous activation of ROS-JNK/ p38 and inhibition of NFкB pathway (Fig. 4F - 4H) may contribute to Lipo-DS/Cu induced cytotoxicity in the $\mathrm{BC}$ cell lines.

In this study, we first reported the anticancer effect of Lipo-DS in combination with copper in vivo. Lipo-DS/CuGlu demonstrated the strongest anticancer efficacy. Lipo-DS injection alone also showed anticancer activity although lower than that of Lipo-DS/CuGlu. This may be due to the intrinsic copper in plasma and tumor tissues [51]. Oral version of $\mathrm{DS} / \mathrm{Cu}$ showed mild in vivo anticancer activity. The Lipo-DS, Lipo-DS/Cu and DS/Cu induced apoptosis was evidenced by TUNEL and western blotting results (Fig. 6C and 6D). Consistence with our in vitro data ([21] and unpublished data) Ki67 staining (Fig. $6 C)$ indicates that the anticancer effect of DS and Lipo$\mathrm{DS}$ is proliferation-independent. In line with the in vitro data, Lipo-DS inhibited the $\mathrm{ALDH}^{+} \mathrm{CSC}$ population in the xenografts (Fig. 6C). To determine the in vivo selectivity DS, the histo-pathological changes of vital organs (liver, lung and kidney) were examined (Fig. 6E). CuGlu induced blood congestion in major organs. There was no significant toxicity observed in the vital organs except that some necrotic cells were observed in the liver of Lipo$\mathrm{DS} / \mathrm{Cu}$ treated mice. Our unpublished data indicate that in combination with $\mathrm{Cu}$, the in vivo anticancer effect of nano-encapsulated DS could be achieved at significantly lower dose with no toxicity in liver. Therefore the dose of Lipo-DS in Lipo-DS/CuGlu group still needs to be adjusted. After very short exposure (1 hour) in vitro, Lipo-DS showed high selectivity and strong irreversible cytotoxicity in cancer cells. This phenomenon gives us a further indication that development of long-circulating formulation of DS may translate this drug into clinical cancer therapeutics.

\section{MATERIALS AND METHODS}

\section{Cell lines and reagents}

The breast cancer cell lines MCF7, MDA-MB-231, T47D and normal breast epithelial cell line MCF10A were purchased from ATCC (Middlesex, UK). HeCV, the normal human vascular endothelial cell line, [52] was kindly provided by Prof W Jiang (Cardiff University, UK). Gemcitabine (dFdC), doxorubicin (Dox), paclitaxel (PTX), copper(II) chloride $\left(\mathrm{CuCl}_{2}\right)$, copper gluconate $(\mathrm{CuGlu})$, $\mathrm{N}$-acetyl-cysteine (NAC) and poly-2-hydroxyethyl methacrylate (poly-HEMA) were purchased from Sigma (Dorset, UK). Lipo-DS was provided by Prof X Tang (Shenyang Pharmaceutical University, China). The drug 
loading content of Lipo-DS is $3 \mathrm{mg} / \mathrm{ml}$. The cumulative release of DS from liposome in $120 \mathrm{~h}$ is more than $60 \%$. The pharmacokinetic study of DSF in rat plasma after intravenous administration of a dose of $36 \mathrm{mg} / \mathrm{kg}$ has been investigated $\left(\mathrm{t}_{1 / 2}=0.1 \mathrm{~h}\right.$ and $\left.\mathrm{t}_{1 / 2 \mathrm{~d}}=0.3 \mathrm{~h}\right)$. The comparison of the biological activity between Lipo-DS and conventional DS has been published [53].

\section{Cell culture and cytotoxicity analysis}

All cell lines were cultured in DMEM (Lonza, Wokingham, UK) supplemented with $10 \%$ FCS, $2 \mathrm{mM}$ L-glutamine, 50 units $/ \mathrm{ml}$ penicillin, $50 \mu \mathrm{g} / \mathrm{ml}$ streptomycin. For in vitro cytotoxicity assay, the cells $(5,000 /$ well) were cultured in 96-well flat-bottomed microtiter plates overnight and exposed to anticancer drugs or Lipo-DS plus $\mathrm{CuCl}_{2}(10 \mu \mathrm{M})$ for $72 \mathrm{~h}$, then subjected to a standard MTT assay [54].

\section{In vitro mammosphere and suspension culture and cytotoxicity assay}

To culture the BC spheres, cells were cultured in poly-HEMA coated ultra-low adherence flasks or plates to prevent cell adhesion. The spheres were cultured, at a density of 10,000 cells/ml, as MSCs or suspension cells (SUS) in stem cell culture medium [SCM, serum-free DMEM-F12 supplemented with B27 (Invitrogen, Paisley, UK), $20 \mathrm{ng} / \mathrm{ml}$ epidermal growth factor (EGF, Sigma), $10 \mathrm{ng} / \mathrm{ml}$ basic fibroblasts growth factor (b-FGF, R \& D System, Abingdon, UK), $10 \mu \mathrm{g} / \mathrm{ml}$ insulin (Sigma)] and full medium (DMEM supplemented with 10\% FCS, $2 \mathrm{mM}$ L-glutamine, 50 units $/ \mathrm{ml}$ penicillin, $50 \mu \mathrm{g} / \mathrm{ml}$ streptomycin) respectively. After 6 days culture, the MSC and SUS cell clusters and spheres were photographed and subjected to further treatments. For in vitro cytotoxicity assay, the MSC or SUS cultured cells were trypsinised and seeded in 96-well plated at a density of 5,000 cells/well and exposed to drugs for $72 \mathrm{~h}$ before MTT assay. $\mathrm{CuCl}_{2}$ $(10 \mu \mathrm{M})$ supplemented culture medium was used in the MTT assay to determine the cytotoxicity of Lipo-DS in MSC and SUS.

\section{Measurement of hypoxia in cell culture}

The hypoxic status was determined using the Hypoxyprobe $^{\mathrm{TM}-1}$ Plus Kit supplied by Hypoxyprobe Inc (Burlington, MA, USA) following the supplier's instruction. For immunocytochemistry assay, the cells were cultured in 8 -well chamber slides at normoxic $(20 \%$ oxygen) or hypoxic [1\% oxygen in Hypoxic Chamber (StemCell, Durham, NC, USA)] condition for 24 hours and labeled with Hypoxyprobe for 2 hours. The hypoxic cells were detected by confocal microscope after stained with FITC-conjugated anti-hypoxyprobe MAb. The CSCs and cells in suspending condition were cultured for 6 days. The MSCs and suspension-cultured cells were labelled with Hypoxyprobe for 24 hours and cytospined at 800 rpm for 3 min to spread the spheres onto Polylysine-coated slides (VWR, Lutterworth, UK). For flow cytometric analysis, the cells were cultured in $25 \mathrm{~cm}$ flasks at the above conditions. After immunocytochemistry staining the cells were subjected to flow cytometric analysis. The hypoxic population was detected using a FACSCalibur flow cytometer with 488-nm blue laser and standard FITC $530 / 30 \mathrm{~nm}$ bandpass filter. To determine the effect of hypoxia on drug sensitivity, the cells were cultured in $1 \%$ oxygen condition at a cell density of $1 \times 10^{3}$ cells/well in 96-well plate for 4 days and exposed to anticancer drugs for another $72 \mathrm{~h}$ before MTT assay. The parallel MTT assay was performed in normoxic condition.

\section{Detection of ALDH positive population}

The ALDH positive population was detected by ALDEFLUOR kit (StemCell Tech., Durham, NC, USA) following the supplier's instruction. The cells $\left(2.5 \times 10^{5}\right)$ were analyzed after stained in ALDH substrate containing assay buffer for $30 \mathrm{~min}$ at $37^{\circ} \mathrm{C}$. The negative control was treated with diethylaminobenzaldehyde (DEAB), a specific ALDH inhibitor.

\section{Flow cytometric analysis of CD24 and CD44 expression}

The adherent or mammosphere cells were trypsinised and passed through a $25 \mathrm{G}$ needle. The cells $\left(2.5 \times 10^{5}\right)$ were incubated with CD24 and CD44 antibodies (BD Pharmingen, Oxford, UK) for $20 \mathrm{~min}$ at $4^{\circ} \mathrm{C}$. Unbound antibodies were washed off with $2 \%$ FCS HBSS (Sigma) and the cells (10,000 events) were examined no longer than 1 hour after staining on a BD Facscalibur.

\section{Immunofluorescent flow cytometric analysis of embryonic stem cell markers}

The expression of Nanog, Oct4 and Sox 2 was determined by immunofluoresent flow cytometry. The sphere and hypoxia-cultured cells were collected by trypsinization. The cells fixed by acetone/methanol and permeabilized by $0.1 \%$ triton-X100. After blocked with 3\% BSA for 1 hour the cells were stained with primary (1:50 dilution) and FITC-conjugated secondary antibodies respectively for 1 hour at RT. The positively stained population was detected using a FACSCalibur flow cytometer with 488-nm blue laser and standard FITC $530 / 30 \mathrm{~nm}$ bandpass filter. 


\section{Western blotting analysis}

The protein expression levels were determined by staining with primary antibodies and relevant HRP conjugated secondary (1:5000, Armersham, Buckinghamshire, UK) antibodies. The primary antibodies (Santa Cruz, CA, USA: Bcl2, Bax, p65, IкB $\alpha$, nucleolin, ALDH1A1, 1A3, 3A1, 2 and cleaved PARP; Novus Bio, Cambridge, UK: HIF2; Abcam, Cambridge, UK: phosphorylated p65_S276; Cell Signaling, Herts, UK: AKT, phosphorylated AKT, Sox2, Oct4, JNK, phosphorylated JNK, cJun, phosphorylated cJun, phosphorylated p38, ERK) were diluted at 1:1000 in 5\% fat-free milk-TBST. Anti- $\alpha$-tubulin (1:8000, Sigma) and nucleolin were used as a loading control. The signal was detected using an ECL Western blotting detection kit (GeneFlow, Staffordshire, UK).

\section{Electrophoretic mobility-shift assays (EMSA)}

Nuclear protein extraction was carried out as previously described [21]. A double-stranded NFkB DNA probe (5'-AGT TGA GGG GAC TTT CCC AGG C-3') was end labeled with biotin. Detection of NFкBoligonucleotide complex was performed using a LightShift chemiluminescent EMSA kit (Pierce, Northumberland, UK). Briefly, nuclear protein $(5 \mu \mathrm{g})$ was incubated with 20 fmol of biotin-labeled oligonucleotide for $20 \mathrm{~min}$ at room temperature in binding buffer consisting of $10 \mathrm{mM}$ Tris at $\mathrm{pH}$ 7.5, $50 \mathrm{mM} \mathrm{KCl}, 1 \mathrm{mM}$ DTT, $2.5 \%$ glycerol, $5 \mathrm{mM}$ $\mathrm{MgCl}_{2}, 50 \mathrm{ng}$ of poly(dIdC), and $0.05 \%$ Nonidet P- 40 . The specificity of the NFKB DNA binding was determined in competition reactions in which a 200 -fold molar excess of unlabeled wild type or mutant NFkB probe (5'-AGT TGA TAT TAC TTT TAT AGG C-3') was added to the binding reaction. Products of binding reactions were resolved by electrophoresis on a $6 \%$ polyacrylamide gel. NFкBoligonucleotide complex was electroblotted onto a nylon membrane (Amersham). After incubation in blocking buffer for 1 hour at room temperature, the membrane was incubated with streptavidin-HRP conjugate for 30 min at room temperature. The membrane was incubated with chemiluminescent substrate for $5 \mathrm{~min}$ and exposed to radiographic film.

\section{Luciferase reporter gene assay}

The effect of different treatments on the transcriptional activity of $\mathrm{NF \kappa B}$ was determined by luciferase reporter gene assays. Transfections were performed using Lipofectamine 2000 transfection reagent according to the manufacturer's instructions (Invitrogen, Paisley, UK). Cells $\left(1 \times 10^{4} /\right.$ well $)$ were cultured in 96 -well plates overnight. The luciferase reporter vectors $(0.8 \mu \mathrm{g} /$ well) [pNFкB-Tal-Luc (BD Biosciences) and pGL3Basic (Promega, Southampton, UK)] were co-transfected with $0.008 \mu \mathrm{g} / \mathrm{well} \mathrm{pSV} 40-$ Renilla (Promega) DNA, an internal control for normalization of the transcriptional activity of the reporter vectors. Twenty-four hours after transfection, the cells were lysed and luciferase activity was determined using Dual Luciferase Assay kit (Promega) according to the manufacturer's instructions. The luciferase activity in each well was normalized to pSV40-Renilla using $\mathrm{Ln}=\mathrm{L} / \mathrm{R}$ (Ln: normalized luciferase activity; L: luciferase activity reading; R: Renilla activity reading). The transcriptional specificity was monitored by the transcriptional activity of the pGL3-Basic. All transfections were performed in triplicate with at least duplicate independent experiments.

\section{Measurement of ROS activity}

The intracellular ROS levels were determined using a Total ROS Detection Kit (Enzo, Exeter, UK) following the supplier's instruction. Briefly, the cancer cells $\left(2 \times 10^{5}\right.$ cells/well) were cultured in 6-well plate until $70 \%$ confluence. The cells were exposed to Lipo-DS $(1 \mu \mathrm{M})$ in combination with $\mathrm{Cu}(10 \mu \mathrm{M})$. Cells exposed to NAC (2 $\mathrm{mM}$ ) were used as a negative control. After drug exposure, the drug containing medium was discarded and the cells were collected by trypsinization. The cell pellets were resuspended and incubated in $500 \mu 1$ of ROS Detection Solution at $37^{\circ} \mathrm{C}$ for $30 \mathrm{~min}$ in the dark. The ROS positive population was detected using a FACSCalibur flow cytometer with $488-\mathrm{nm}$ blue laser and standard FITC $530 / 30 \mathrm{~nm}$ bandpass filter.

\section{Clonogenic Assay}

Cells $\left(5 \times 10^{4} /\right.$ well $)$ were cultured in 6 -well plates overnight and then exposed to $1 \mu \mathrm{M}$ of DS in combination with $10 \mu \mathrm{M} \mathrm{CuCl}_{2}$ for $1 \mathrm{~h}$. The cells were collected and cultured in 6-well plates containing drug-free medium at a cell density of $2.5 \times 10^{3} /$ well. Clonogenic cells were determined as those able to form a colony consisting of at least 50 cells after 10 days culture.

\section{Total RNA isolation and RT-PCR}

Total RNA was isolated using TRIzol reagent (Invitrogen, Paisley, UK) according to the manufacturer's protocols. The mRNA expression levels of ALDH 1A1 (NM_000689), 1A3 (NM_000693), 2 (NM_000690) and $3 \mathrm{~A} 1$ (NM_000691) genes were determined using the Access RT-PCR System (Promega, Southampton, UK) following the instruction of the supplier. The human housekeeping gene GAPDH (XR018317) was used as the RNA loading control. The sequences of the primers 
and the sizes of the amplified fragments are as follows. 1A1 (154 bp): F: 5'-TGTTAGCTGATGCCGACTTG-3', R: 5'-TTCTTAGCCCGCTCAACACT-3'; 1A3 (150 bp): F: 5'-TCTCGACAAAGCCCTGAAGT-3', R: 5'-TATTCGGCCAAAGCGTATTC-3'; ALDH2 (193 bp) F: 5'- AACCAGCAGCCCGAGGTCTT-3', R: 5'- AAGGTGAGCCCAGCTGGAAG-3'; 3A1 (229 bp) F: 5'-TGTTCTCCAGCAACGACAAG-3', R: 5'-CTGACCTTCAGGCCTTCATC-3'; GAPDH (226bp) F: 5'-GAAGGTGAAGGTCGGAGTC-3', R: 5'- GAAGATGGTGATGGGATTTC-3'. The RT-PCR conditions were as follows: One cycle at $48^{\circ} \mathrm{C}$ for $45 \mathrm{~min}$; 1 cycle at $94^{\circ} \mathrm{C}$ for $2 \mathrm{~min} ; 35$ cycles at $94^{\circ} \mathrm{C}$ for $30 \mathrm{sec}$, $60^{\circ} \mathrm{C}$ for $30 \mathrm{sec}, 72^{\circ} \mathrm{C}$ for $1 \mathrm{~min} ; 1$ cycle at $72^{\circ} \mathrm{C}$ for $5 \mathrm{~min}$.

\section{Human breast cancer xenograft experiments}

Five-week-old female BALB/c Nu/Nu athymic nude mice (Biotechology \& Cell Biology Shanghai, China) were housed under pathogen-free conditions according to the animal care guidelines of Fourth Military Medical University (FMMU), China. The animal experiments were reviewed and approved by the Ethical Committee of FMMU. The animal study regimen is detailed in Fig. 6 . The tumor volume was calculated by the following formula: $\mathrm{V}=\left(\mathrm{L} \times \mathrm{W}^{2}\right) \times 0.5$, where $\mathrm{L}$ is the length and $\mathrm{W}$ is the width of the tumor. The xenograft size was observed twice per week for 4 weeks. After 4 weeks or when the xenograft reached $1500 \mathrm{~mm}^{3}$, the animals were sacrificed. The tumors were removed, photographed and subjected to further analysis.

\section{Immunohistochemistry and H\&E staining}

The paraffin embedded tumor and normal tissue sections were stained using Ki67 (1:200, Cell signaling) and ALDH1 (1:100, Abcam) antibodies then stained with biotinylated anti-mouse immunoglobulin $\mathrm{G}(\mathrm{H}+$ L) secondary antibody followed by incubation in ABC reagent (DAKO Labs, Cambridgeshire, UK). For H\&E staining, the slides were deparaffinized, rehydrated and stained with hematoxylin and eosin for 1 minute. The slide was mounted with 3,3'-diaminobenzidine and visualized under a light microscope.

\section{Terminal deoxyribonucleotidyl transferase- mediated dUTP nick end labeling (TUNEL) assay}

Tumor tissues were paraffin embedded and stained according to the instruction of the manufacturer (Roche, West Sussex, UK). Briefly, the slides were incubated with TdT Enzyme, Stop/Wash Buffer, antidigoxigenenin, and then stained with peroxidase substrate and incubated in $\mathrm{ABC}$ reagent. Finally, the slide was mounted with 3,3'-diaminobenzidine and visualized under a light microscope.

\section{Statistical Analysis}

SPSS 13.0 Student's $t$ test and one way analysis of variance (ANOVA) followed by Tukey's Multiple Comparison Test were used to calculate the differences. Data were expressed as mean \pm SD. $\mathrm{P} \leq 0.05$ was considered as significantly change.

\section{ACKNOWLEDGEMENTS}

This project was supported by Breast Cancer Campaign (UK) and Marie-Curie IIF Program (PIIFGA-2013-629478).

\section{Conflicts of Interest}

No potential conflicts of interest were disclosed by any of the authors.

\section{REFERENCES}

1. Dalerba P, Cho RW and Clarke MF. Cancer stem cells: models and concepts. Annu Rev Med. 2007; 58:267-284.

2. Tirino V, Desiderio V, Paino F, De Rosa A, Papaccio F, La Noce M, Laino L, De Francesco F and Papaccio G. Cancer stem cells in solid tumors: an overview and new approaches for their isolation and characterization. Faseb J. 2013; 27(1):13-24.

3. Marques DS, Sandrini JZ, Boyle RT, Marins LF and Trindade GS. Relationships between multidrug resistance (MDR) and stem cell markers in human chronic myeloid leukemia cell lines. Leuk Res. 2010; 34(6):757-762.

4. Storci G, Sansone P, Mari S, D’Uva G, Tavolari S, Guarnieri T, Taffurelli M, Ceccarelli C, Santini D, Chieco P, Marcu KB and Bonafe M. TNFalpha up-regulates SLUG via the NF-kappaB/HIF1alpha axis, which imparts breast cancer cells with a stem cell-like phenotype. J Cell Physiol. 2010; 225(3):682-691.

5. Simsek T, Kocabas F, Zheng J, Deberardinis RJ, Mahmoud AI, Olson EN, Schneider JW, Zhang CC and Sadek HA. The distinct metabolic profile of hematopoietic stem cells reflects their location in a hypoxic niche. Cell Stem Cell. 2010; 7(3):380-390.

6. Bao B, Azmi AS, Ali S, Ahmad A, Li Y, Banerjee S, Kong D and Sarkar FH. The biological kinship of hypoxia with CSC and EMT and their relationship with deregulated expression of miRNAs and tumor aggressiveness. Biochim Biophys Acta. 2012; 1826(2):272-296.

7. Clevers H. The cancer stem cell: premises, promises and challenges. Nat Med. 2011; 17(3):313-319. 
8. Zeng W, Wan R, Zheng Y, Singh SR and Wei Y. Hypoxia, stem cells and bone tumor. Cancer Lett. 2011; 313(2):129136.

9. Cummins EP and Taylor CT. Hypoxia-responsive transcription factors. Eur J Physiol. 2005; 450(6):363-371.

10. Arlt A, Gehrz A, Muerkoster S, Vorndamm J, Kruse ML, Folsch UR and Schafer H. Role of NF-kappaB and Akt/ $\mathrm{PI} 3 \mathrm{~K}$ in the resistance of pancreatic carcinoma cell lines against gemcitabine-induced cell death. Oncogene. 2003; 22(21):3243-3251.

11. Wang W, McLeod HL, Cassidy J and Collie-Duguid ES. Mechanisms of acquired chemoresistance to 5-fluorouracil and tomudex: thymidylate synthase dependent and independent networks. Cancer Chemother Pharmacol. 2007; 59(6):839-845.

12. Walmsley SR, Print C, Farahi N, Peyssonnaux C, Johnson RS, Cramer T, Sobolewski A, Condliffe AM, Cowburn AS, Johnson $\mathrm{N}$ and Chilvers ER. Hypoxia-induced neutrophil survival is mediated by HIF-1alpha-dependent NF-kappaB activity. J Exp Med. 2005; 201(1):105-115.

13. Scortegagna M, Cataisson C, Martin RJ, Hicklin DJ, Schreiber RD, Yuspa SH and Arbeit JM. HIF-1alpha regulates epithelial inflammation by cell autonomous NFkappaB activation and paracrine stromal remodeling. Blood. 2008; 111(7):3343-3354.

14. Culver C, Sundqvist A, Mudie S, Melvin A, Xirodimas D and Rocha S. Mechanism of hypoxia-induced NF-kappaB. Mol Cell Biol. 2010; 30(20):4901-4921.

15. Belaiba RS, Bonello S, Zahringer C, Schmidt S, Hess J, Kietzmann $\mathrm{T}$ and Gorlach A. Hypoxia up-regulates hypoxia-inducible factor-1alpha transcription by involving phosphatidylinositol 3-kinase and nuclear factor kappaB in pulmonary artery smooth muscle cells. Mol Biol Cell. 2007; 18(12):4691-4697.

16. van Uden P, Kenneth NS and Rocha S. Regulation of hypoxia-inducible factor-1alpha by NF-kappaB. Biochem J. 2008; 412(3):477-484.

17. Bracken CP, Whitelaw ML and Peet DJ. Activity of hypoxia-inducible factor 2alpha is regulated by association with the NF-kappaB essential modulator. J Biol Chem. 2005; 280(14):14240-14251.

18. Tian J, Yan J, Wang W, Zhong N, Tian L, Sun J, Min Z, Ma J and Lu S. T-2 toxin enhances catabolic activity of hypertrophic chondrocytes through ROS-NF-kappaB-HIF2alpha pathway. Toxicology in vitro. 2012; 26(7):11061113.

19. Mannello F, Medda V and Tonti GA. Hypoxia and neural stem cells: from invertebrates to brain cancer stem cells. Int J Dev Biol. 2011; 55(6):569-581.

20. Schreck R, Meier B, Mannel DN, Droge W and Baeuerle PA. Dithiocarbamates as potent inhibitors of nuclear factor kappa B activation in intact cells. J Exp Med. 1992; 175(5):1181-1194.

21. Yip NC, Fombon IS, Liu P, Brown S, Kannappan V,
Armesilla AL, Xu B, Cassidy J, Darling JL and Wang W. Disulfiram modulated ROS-MAPK and NFkB pathways and targeted breast cancer cells with cancer stem cell like properties. Br J Cancer. 2011; 104(10):1564-1574.

22. Chen D, Cui QC, Yang H and Dou QP. Disulfiram, a clinically used anti-alcoholism drug and copper-binding agent, induces apoptotic cell death in breast cancer cultures and xenografts via inhibition of the proteasome activity. Cancer Res. 2006; 66(21):10425-10433.

23. Kast RE, Boockvar JA, Bruning A, Cappello F, Chang WW, Cvek B, Dou QP, Duenas-Gonzalez A, Efferth T, Focosi D, Ghaffari SH, Karpel-Massler G, Ketola K, Khoshnevisan A, Keizman D, Magne N, et al. A conceptually new treatment approach for relapsed glioblastoma: coordinated undermining of survival paths with nine repurposed drugs (CUSP9) by the International Initiative for Accelerated Improvement of Glioblastoma Care. Oncotarget. 2013; 4(4):502-530.

24. Hothi P, Martins TJ, Chen LP, Deleyrolle L, Yoon JG, Reynolds B and Foltz G. High-throughput chemical screens identify disulfiram as an inhibitor of human glioblastoma stem cells. Oncotarget. 2012; 3(3):1124-1136.

25. Wang W, McLeod HL and Cassidy J. Disulfiram-mediated inhibition of NF-kappaB activity enhances cytotoxicity of 5 -fluorouracil in human colorectal cancer cell lines. Int $\mathrm{J}$ Cancer. 2003; 104(4):504-511.

26. Guo X, Xu B, Pandey S, Goessl E, Brown J, Armesilla AL, Darling JL and Wang W. Disulfiram/copper complex inhibiting NFkappaB activity and potentiating cytotoxic effect of gemcitabine on colon and breast cancer cell lines. Cancer Lett. 2010; 291(1):104-113.

27. Liu P, Brown S, Goktug T, Channathodiyil P, Kannappan V, Hugnot JP, Guichet PO, Bian X, Armesilla AL, Darling $\mathrm{JL}$ and Wang W. Cytotoxic effect of disulfiram/copper on human glioblastoma cell lines and ALDH-positive cancerstem-like cells. Br J Cancer. 2012; 107(9):1488-1497.

28. Dufour P, Lang JM, Giron C, Duclos B, Haehnel P, Jaeck D, Jung JM and Oberling F. Sodium dithiocarb as adjuvant immunotherapy for high risk breast cancer: a randomized study. Biotherapy. 1993; 6(1):9-12.

29. Cen D, Brayton D, Shahandeh B, Meyskens FL, Jr. and Farmer PJ. Disulfiram facilitates intracellular $\mathrm{Cu}$ uptake and induces apoptosis in human melanoma cells. J Med Chem. 2004; 47(27):6914-6920.

30. Nobel CI, Kimland M, Lind B, Orrenius S and Slater AF. Dithiocarbamates induce apoptosis in thymocytes by raising the intracellular level of redox-active copper. J Biol Chem. 1995; 270(44):26202-26208.

31. Estey T, Piatigorsky J, Lassen $\mathrm{N}$ and Vasiliou V. ALDH3A1: a corneal crystallin with diverse functions. Exp Eye Res. 2007; 84(1):3-12.

32. Ginestier C, Hur MH, Charafe-Jauffret E, Monville F, Dutcher J, Brown M, Jacquemier J, Viens P, Kleer CG, Liu S, Schott A, Hayes D, Birnbaum D, Wicha MS and 
Dontu G. ALDH1 is a marker of normal and malignant human mammary stem cells and a predictor of poor clinical outcome. Cell Stem Cell. 2007; 1(5):555-567.

33. Loo TW, Bartlett MC and Clarke DM. Disulfiram metabolites permanently inactivate the human multidrug resistance P-glycoprotein. Mol Pharm. 2004; 1(6):426-433.

34. Brar SS, Grigg C, Wilson KS, Holder WD, Jr., Dreau D, Austin C, Foster M, Ghio AJ, Whorton AR, Stowell GW, Whittall LB, Whittle RR, White DP and Kennedy TP. Disulfiram inhibits activating transcription factor/cyclic AMP-responsive element binding protein and human melanoma growth in a metal-dependent manner in vitro, in mice and in a patient with metastatic disease. Mol Cancer Ther. 2004; 3(9):1049-1060.

35. Liu P, Kumar IS, Brown S, Kannappan V, Tawari PE, Tang JZ, Jiang W, Armesilla AL, Darling JL and Wang W. Disulfiram targets cancer stem-like cells and reverses resistance and cross-resistance in acquired paclitaxelresistant triple-negative breast cancer cells. Br J Cancer. 2013.

36. Marcato P, Dean CA, Pan D, Araslanova R, Gillis M, Joshi M, Helyer L, Pan L, Leidal A, Gujar S, Giacomantonio CA and Lee PW. Aldehyde Dehydrogenase Activity of Breast Cancer Stem Cells Is Primarily Due To Isoform ALDH1A3 and Its Expression Is Predictive of Metastasis. Stem Cells. 29(1):32-45.

37. Zhang F, Song C, Ma Y, Tang L, Xu Y and Wang H. Effect of fibroblasts on breast cancer cell mammosphere formation and regulation of stem cell-related gene expression. Int $\mathrm{J}$ Mol Med. 2011; 28(3):365-371.

38. Moreb JS, Ucar D, Han S, Amory JK, Goldstein AS, Ostmark B and Chang LJ. The enzymatic activity of human aldehyde dehydrogenases 1A2 and 2 (ALDH1A2 and ALDH2) is detected by Aldefluor, inhibited by diethylaminobenzaldehyde and has significant effects on cell proliferation and drug resistance. Chem Biol Interact. 2011; 195(1):52-60.

39. Al-Hajj M, Wicha MS, Benito-Hernandez A, Morrison SJ and Clarke MF. Prospective identification of tumorigenic breast cancer cells. Proc Natl Acad Sci U S A. 2003; 100(7):3983-3988.

40. Kreso A and Dick JE. Evolution of the Cancer Stem Cell Model. Cell Stem Cell. 2014; 14(3):275-291.

41. Singec I, Knoth R, Meyer RP, Maciaczyk J, Volk B, Nikkhah G, Frotscher M and Snyder EY. Defining the actual sensitivity and specificity of the neurosphere assay in stem cell biology. Nature methods. 2006; 3(10):801-806.

42. Hinohara K, Kobayashi S, Kanauchi H, Shimizu S, Nishioka K, Tsuji E, Tada K, Umezawa K, Mori M, Ogawa $\mathrm{T}$, Inoue J, Tojo A and Gotoh N. ErbB receptor tyrosine kinase/NF-kappaB signaling controls mammosphere formation in human breast cancer. Proc Natl Acad Sci U S A. 2012; 109(17):6584-6589.

43. Liu M, Sakamaki T, Casimiro MC, Willmarth NE, Quong
AA, Ju X, Ojeifo J, Jiao X, Yeow WS, Katiyar S, Shirley LA, Joyce D, Lisanti MP, Albanese C and Pestell RG. The canonical NF-kappaB pathway governs mammary tumorigenesis in transgenic mice and tumor stem cell expansion. Cancer Res. 2010; 70(24):10464-10473.

44. Myant KB, Cammareri P, McGhee EJ, Ridgway RA, Huels DJ, Cordero JB, Schwitalla S, Kalna G, Ogg EL, Athineos D, Timpson P, Vidal M, Murray GI, Greten FR, Anderson KI and Sansom OJ. ROS production and NF-kappaB activation triggered by RAC1 facilitate WNT-driven intestinal stem cell proliferation and colorectal cancer initiation. Cell Stem Cell. 2013; 12(6):761-773.

45. Triscott J, Lee C, Hu K, Fotovati A, Berns R, Pambid M, Luk M, Kast RE, Kong E, Toyota E, Yip S, Toyota B and Dunn SE. Disulfiram, a drug widely used to control alcoholism, suppresses self-renewal of glioblastoma and overrides resistance to temozolomide. Oncotarget. 2012; Epub ahead of print.

46. Johansson B. A review of the pharmacokinetics and pharmacodynamics of disulfiram and its metabolites. Acta Psychiatr Scand Suppl. 1992; 369:15-26.

47. Wang W. Disulfiram formulation and uses thereof. WO 2010/076897 A1. 2010.

48. Gloire G, Legrand-Poels S and Piette J. NF-kappaB activation by reactive oxygen species: fifteen years later. Biochem Pharmacol. 2006; 72(11):1493-1505.

49. Junttila MR, Li SP and Westermarck J. Phosphatasemediated crosstalk between MAPK signaling pathways in the regulation of cell survival. FASEB J. 2008; 22(4):954965.

50. Nakano H, Nakajima A, Sakon-Komazawa S, Piao JH, Xue X and Okumura K. Reactive oxygen species mediate crosstalk between NF-kappaB and JNK. Cell Death Differ. 2006; 13(5):730-737.

51. Margalioth EJ, Schenker JG and Chevion M. Copper and zinc levels in normal and malignant tissues. Cancer. 1983; 52(5):868-872.

52. Webb SL, Sanders AJ, Mason MD and Jiang WG. Matriptase-2 inhibits HECV motility and tubule formation in vitro and tumour angiogenesis in vivo. Mol Cell Biochem. 2013; 375(1-2):207-217.

53. Zhang L, Jiang Y, Jing G, Tang Y, Chen X, Yang D, Zhang $Y$ and Tang X. A novel UPLC-ESI-MS/MS method for the quantitation of disulfiram, its role in stabilized plasma and its application. J Chromatogr B Analyt Technol Biomed Life Sci. 2013; 937:54-59.

54. Plumb JA, Milroy $\mathrm{R}$ and Kaye SB. Effects of the $\mathrm{pH}$ dependence of 3-(4,5-dimethylthiazol-2-yl)-2,5diphenyl-tetrazolium bromide-formazan absorption on chemosensitivity determined by a novel tetrazolium-based assay. Cancer Res. 1989; 49(16):4435-4440. 